\title{
Utilization of Anadara granosa as A Liming Materials for Swamp Fish Ponds for Pangasius sp. Culture
}

\author{
Dade Jubaedah $^{\left.1^{*}\right)}$, Marsi ${ }^{2}$, and Rani Ria Rizki ${ }^{3}$ \\ ${ }^{1,3}$ Aquaculture Study Program, Sriwijaya University, Palembang, Indonesia \\ ${ }^{2}$ Soil Science Department, Sriwijaya University, Palembang Indonesia \\ Email: dade.jubaedah@gmail.com ${ }^{*}$; dadejubaedah@fp.unsri.ac.id; raniria39@gmail.com,mbasihin1960@yahoo.com
}

\begin{abstract}
Dade Jubaedah, Marsi, and Rani Ria Rizki. 2017. Utilization of Anadara granosa as A Liming Materials for Swamp Fish Ponds for Pangasius sp. Culture. Aquacultura Indonesiana, 18 (2): $48-54$. Availability of water in swamp areas is abandon almost throughout the year, therefore these areas are potential for aquaculture development. However, the characteristics of swamp water is mainly acid water, therefore, it becomes mayor problems in swamp fish culture development. Liming of ponds is intended to increase $\mathrm{pH}$ value of soil and water of fish ponds. A. granosa shells is one of domestic waste containing of $61.16 \% \mathrm{CaO}$ and $21.65 \% \mathrm{MgO}$, therefore it can be used as an alternative material for liming of fish ponds. The aims of this research was to evaluate the potency of lime derived from A. granosa shells to raise soil's and water's pH, and to evaluate its effect to survival and growth of Pangasius $s p$. The research was conducted and arranged based upon completely randomized design with five treatments and three replications. The treatments used consisted of different dosages of lime, namely : P1) 1 ton/ha; P2) 2 ton/ha; P3) 3 ton/ha; P4) 4 ton/ha and P5) 5 ton/ha of lime equivalent to $\mathrm{CaO}$. The results showed that both the soil and water reach a neutral $\mathrm{pH}$ at a dosage of 2 ton/ha (P2), 3 ton/ha (P3), 4 ton/ha and 5 ton/ha. The dosage of 5 ton/ha (P5) was the best treatments among all treatments, with a highest survival rate $(100 \%)$, absolute growth of fish lenght $(9.35 \mathrm{~cm})$ and weight $(40.69 \mathrm{~g})$, as well as feed efficiency (110.97\%).
\end{abstract}

Keywords: Anadara granosa; Lime; Pangasius sp; pH; Swamp

\section{Introduction}

Swamp is a wetland that receives a relatively rich supply of nutrients and often also sediment via surface runoff and groundwater from adjacent land. Swamps usually have a combination of mineral and peat substrates. Leads of standing water or surface channels are often present, with gentle permanent or periodic internal flow. Soil water table is high near soil surface, even at some area permanently above or periodically above soil surface. The soil's pH of swamps is 5.9 (Vijayakumar and Vasudeva, 2011), and $\mathrm{pH}$ of swamp water ranged from 4.8 to 6.3 (Johnson and Gerbeaux, 2004). Meanwhile, the downstream of swamp water namely floodplain, has $\mathrm{pH}$ value ranged from 4.7 to 5.6 (Jubaedah et al., 2015).

Ponds built in areas that have acid soils and soft water may not always perform well for fish production (Wynne, 1996). It is desirable to provide cultured fish with conditions that are within their favoured range for optimum growth and production. According to Wilkinson (2002), pond waters with $\mathrm{pH}$ of 3.6-5.4 have been reported to exert effects on a range of fishes including mortality, reduced growth and poor reproduction.

Liming of ponds is intended to increase soil and water fish ponds $\mathrm{pH}$ value. Liming materials are used widely in aquaculture, mainly to neutralize acidity in pond soil and water, to increase alkalinity and hardness of water, and to destroy disease carriers in soil (Boyd et al., 2002). Some of liming materials currently use, e.q. calcitic lime $\left(\mathrm{CaCO}_{3}\right)$, dolomictic lime $\left(\mathrm{CaMgCO}_{3}\right)$, Hydrated lime $\left(\mathrm{Ca}(\mathrm{OH})_{2}\right)$, and quicklime $(\mathrm{CaO})$. Blends liming materials also can be used as alternative liming material, e.q. $\mathrm{CaCO}_{3}$ following by $\mathrm{Na}_{2} \mathrm{CO}_{3}+\mathrm{CaSO}_{4}$ and $\mathrm{Na}_{2} \mathrm{CO}_{3}+\mathrm{CaCl}_{2}$ (Nobre et al., 2014). The other alternative liming materials are industrial by product and domestic waste containing a high percentage of calcium and/or magnesium carbonate $\left(\mathrm{CaCO}_{3}\right)$.

Anadara granosa shells is one of domestic waste that potential to use as liming materials. Every $\mathrm{kg}$ of A. granosa shells can produce 0.915 $\mathrm{kg}$ lime containing $\mathrm{CaO} 61.16 \%$ and $\mathrm{MgO}$ $21.65 \%$. The aims of this research were to use $A$. granosa shells as liming materials in swamp fish ponds to increase soil's and water's $\mathrm{pH}$ and to improve survival and growth of Pangasius sp.

\section{Materials and Methods}

The study was conducted from January May 2017 at Field Laboratory, Aquaculture Study Program, Faculty of Agriculture, Sriwijaya 
University, Palembang, South Sumatera Province, Indonesia.

\section{Preparing Lime Materials and Liming}

A. granosa shells was activated by burning in a furnace at temperature $800^{\circ} \mathrm{C}$ for an hour, then was mashed and sieved with 60, 40 and 20 meshsize sieves in order to get lime with 50\% passed 60 mesh-size sieve, $25 \%$ passed 40 mesh-sized sieve, and $25 \%$ passed 20 mesh-size sieve. Five liming treatments were investigated, namely : P1) 1 ton/ha; P2) 2 ton/ha; P3) 3 ton/ha; P4) 4 ton/ha and P5) 5 ton/ha of lime equvalent to $\mathrm{CaO}$ for each pond. Lime derived from A. granosa shells was applied homogeneously on soil ponds and incubated for 7 days. Ponds were then filled with water and let equilibrated for 3 days before fish was stocked. Thus, initial fish culture was 10 days after liming.

\section{Fish Culture}

The study was conducted at field laboratory of Aquaculture Study Program, Faculty of Agriculture, Sriwijaya University, from January to May 2017. Fifteen fish ponds were filled with 105 L swamp water at 7 days after liming. Three hundreds of $8 \pm 0.5 \mathrm{~cm}$ length Pangasius $s p$ were acclimatized in swamp water for one week before being used in the study. Then, every pond was stocked with 20 fish at 10 days after liming. The fishes were fed to satiation three times per day an artificial diet containing $40 \%$ protein. For the 90 days of cultured period (starting at 10 days after liming), water samples were collected and analyzed, as well as growth of fish was measured every ten days.

\section{Experimental variables and analytical procedurs}

Water quality, survival and growth performance variables were observed in the present work. The water's $\mathrm{pH}$, total alkalinity, total hardness, and total ammonia were monitored monthly in all pond. Besides, water temperature and $\mathrm{pH}$ were recorded daily. The water $\mathrm{pH}$ was measured by using a portable $\mathrm{pH}$ meter. The water temperature was observed by the use of a digital handy thermometer. The analytical determinations of total alkalinity, total hardness, and total ammonia were carried out according to the guidelines presented by APHA (2012). The fish final body weight and length, survival and feed efficiency were observed in all experimental units.

Water quality, survival and growth performance result were statistically analized according to the two-way Anova to detect if there were significant differences between experimental treatments. When the differences were significant, the means were compared using the Least Significant Difference test. The 5\% significance level was adopted in all statistical analysis.

\section{Data Analysis}

The fish survival rate was calculated from the initial number of fish and mortality after the experiment was completed. The absolute growth of fishes were determined from initial and final weight and length of fishes at the end of the experiment, respectively for absolute weight growth and lenght growth. Meanwhile, feed efficiency was calculated by the formula as follows:

$$
\mathrm{FE}=\{(\mathrm{wt}+\mathrm{D})-\mathrm{wo}) / \mathrm{F})\} \times 100 \%
$$

Where :

$$
\begin{aligned}
& \mathrm{FE}=\text { feed efficiency } \\
& \mathrm{Wt}=\text { total final fish weight } \\
& \mathrm{Wo}=\text { total initial fish weight } \\
& \mathrm{D}=\text { weight of dead fish } \\
& \mathrm{F}=\text { total feed consumption }
\end{aligned}
$$

\section{Result}

The initial soil's $\mathrm{pH}$ used in this current study was 3.6 and then soil's $\mathrm{pH}$ increased due to liming to $\mathrm{pH} 6.5 \pm 0.5$ after incubated for 7 days. Corelation between incubation time and $\mathrm{pH}$ of soil showed polynomial quadratic patern (Figure $1)$.

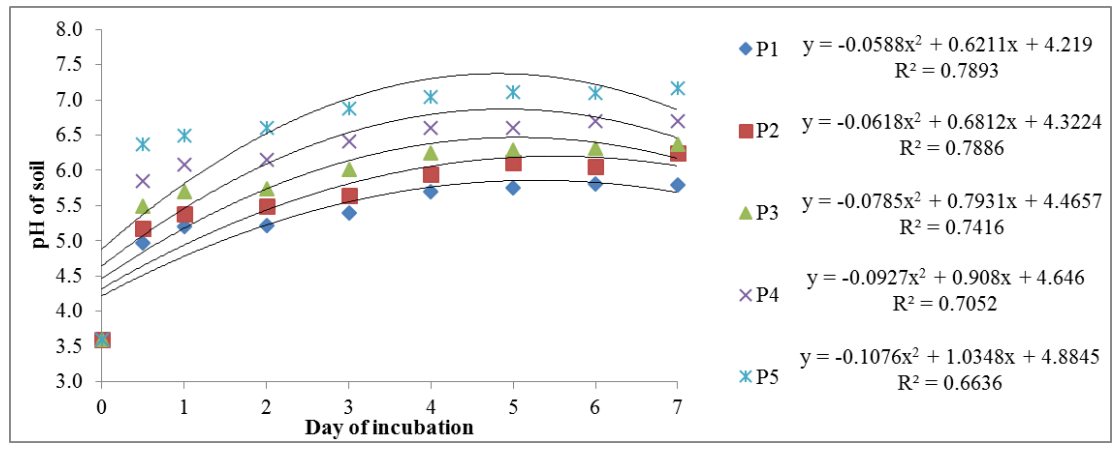

Figure. 1. Relationship between day of incubation and soil's $\mathrm{pH}$ 
The relationship between lime dosage and soil's $\mathrm{pH}$ showed that at 0 after liming (soil's $\mathrm{pH}$ measured approximately 10 hours before fish stocking) the relationship was positively linear pattern, but at day 30,60 and 90 the relationship were polynomial quadratic patterns (Figure 2). The relationship between days of culture and $\mathrm{pH}$ of soils showed that all treatments have polynomial quadratic patterns (Figure 3 ).
The initial water $\mathrm{pH}$ used in this research was 3.9, then water $\mathrm{pH}$ increased following polynomial quadratic patterns for 90 days of fish culture due to lime application (Figure 4). The water alkalinity increased with increasing of dosage of lime (Figure 5). The water alkalinty and hardness increased as $\mathrm{pH}$ of water increased according to equations shown in Figure 6 and Figure 7, respectively.

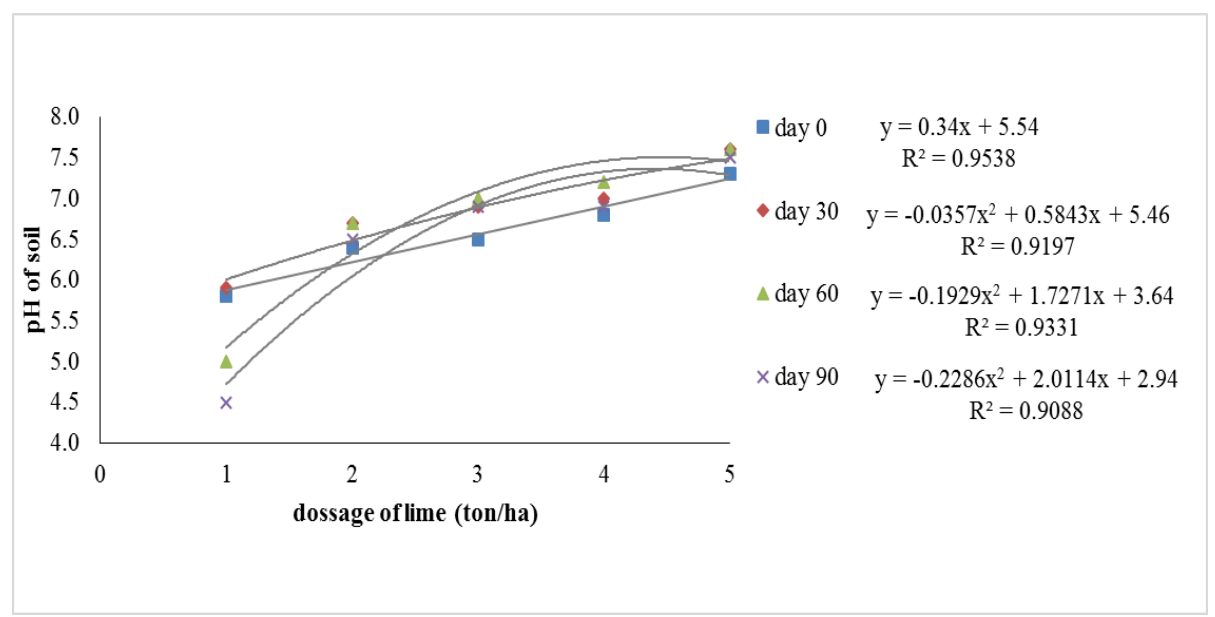

Figure 2. Relationship between dosage of lime and soil's $\mathrm{pH}$ for each observed day

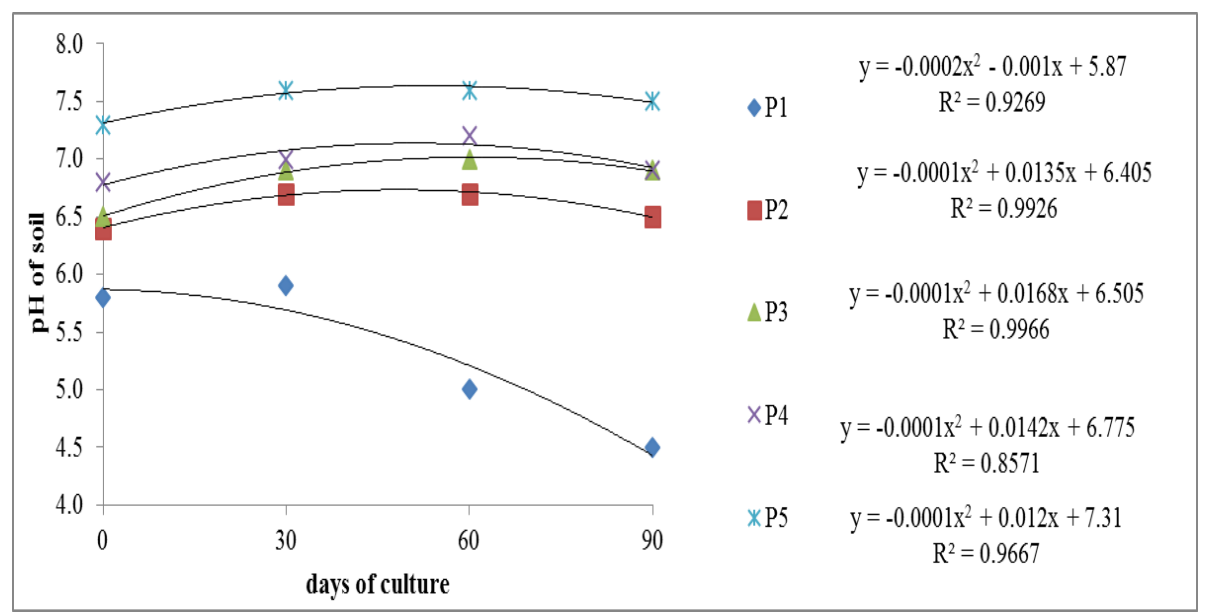

Figure 3. Relationship between days of culture and soil's $\mathrm{pH}$ for each treatments

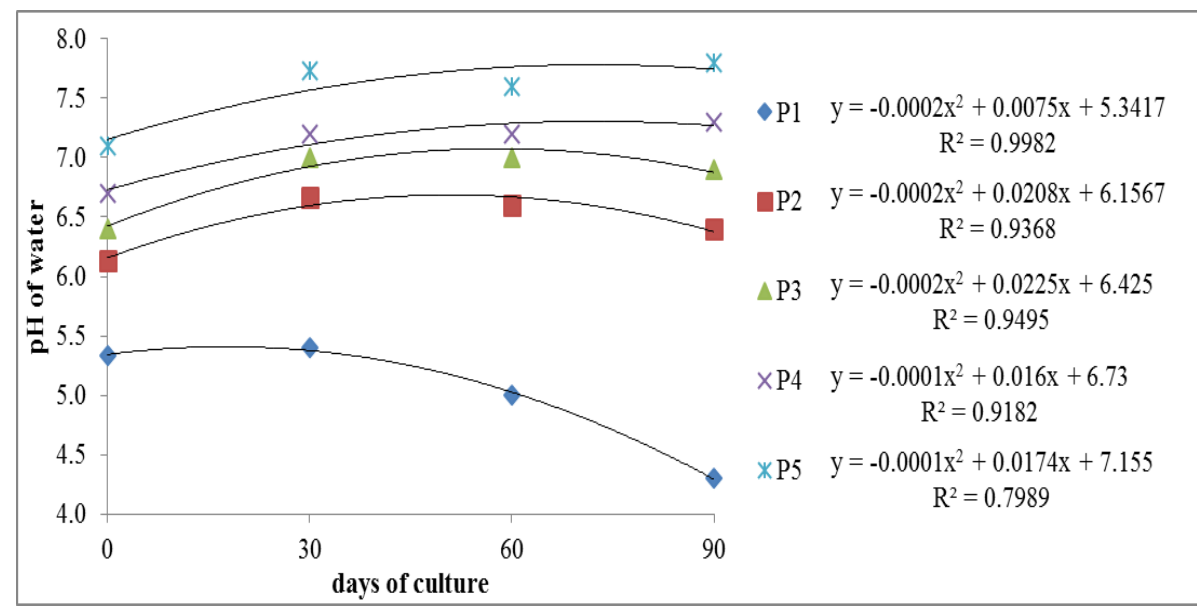

Figure 4. Relationship between days culture and water's $\mathrm{pH}$ for each treatments 


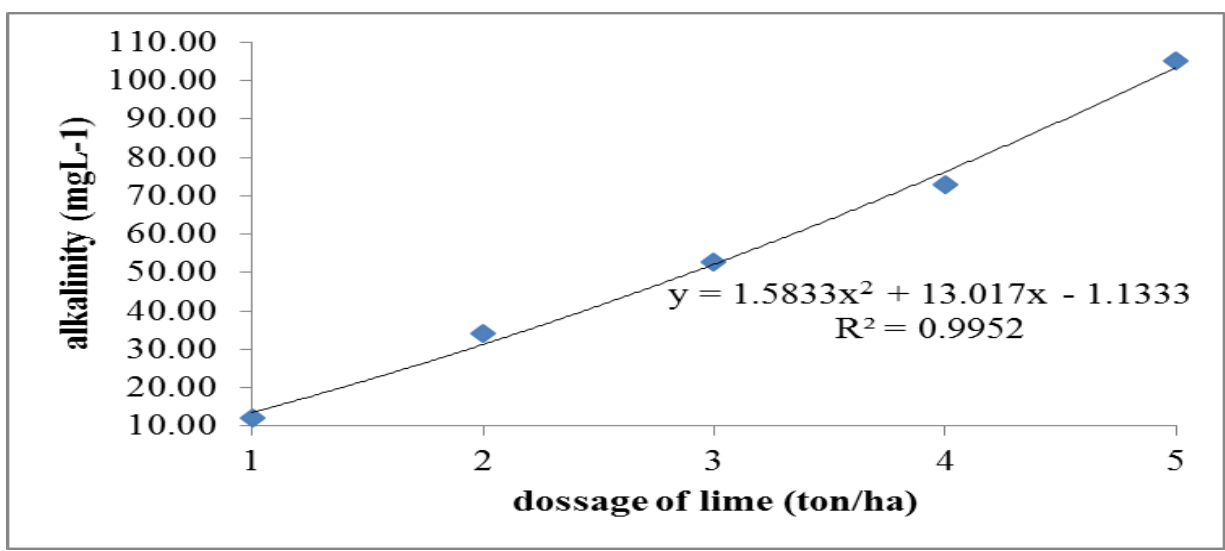

Figure 5. Relationship between dosage of lime and water alkalinity

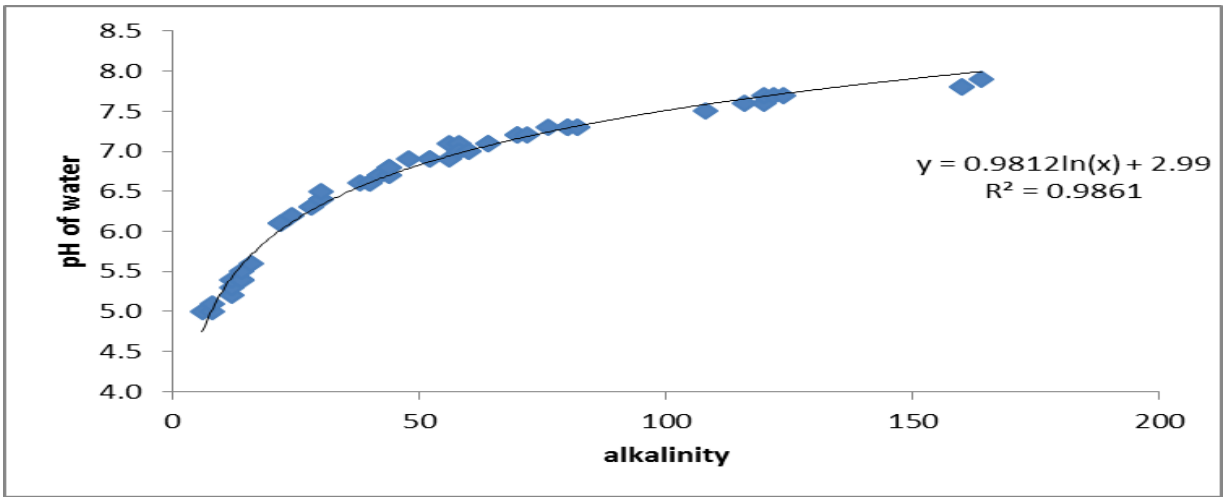

Figure 6 . Reationship between alkalinity and $\mathrm{pH}$ of water

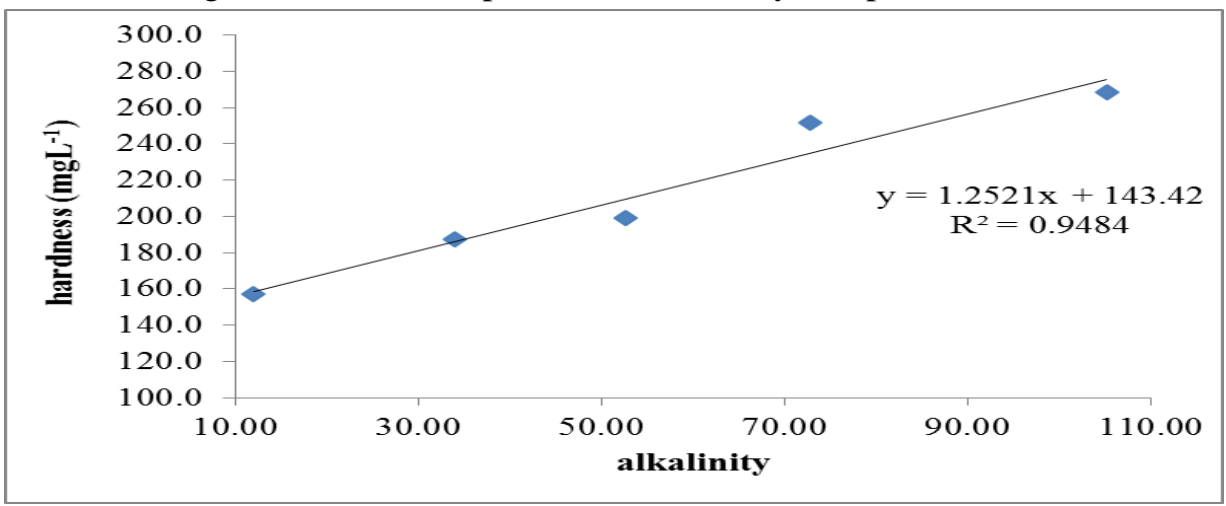

Figure 7. Relationship between water alkalinity and hardness

The water temperature and dissolved oxygen (DO) of ponds (Table 1) ranged from 25.3 to 32.2 and from 3.12 to $7.13 \mathrm{mgL}^{-1}$, respectively.

Table 1. Temperature and dissolved oxygen range for each treatments

\begin{tabular}{ccc}
\hline Treatments & $\begin{array}{c}\text { Temperature } \\
\text { range }\left({ }^{\circ} \mathrm{C}\right)\end{array}$ & $\begin{array}{c}\text { Dissolved } \\
\text { Oxygen }\left(\mathrm{mgL}^{-1}\right)\end{array}$ \\
\hline P1 $(1$ ton/ha) & $25.3-31.7$ & $3.98-6.30$ \\
P2 (2 ton/ha) & $25.4-32.0$ & $3.68-6.62$ \\
P3 (3 ton/ha) & $25.3-32.0$ & $3.23-6.82$ \\
P4 (4 ton/ha) & $25.4-32.1$ & $3.54-7.13$ \\
P5 (5 ton/ha) & $25.2-32.2$ & $3.12-6.87$ \\
\hline
\end{tabular}

The survival rate of Pangasius sp. ranged from $67.00 \pm 2.8 \%$ and $100.00 \pm 0.00 \%$. On average, survival rate for all treatments was $90.67 \pm$
$13.35 \%$. The survival, absolute growth (both weight and length), and feed efficiency was significantly affected by dosage of lime application ( $>0.05$ ) (Table 2). Based on LSD test showed that P4 and P5 (dosage of lime 4 and 5 ton/ha equcalent to $\mathrm{CaO}$ ) were the highest survival rate but no significant difference with that of P3 (dosage of lime 3 ton/ha). Meanwhile, $\mathrm{P} 5$ (dosage 5 ton/ha equvalent to $\mathrm{CaO}$ ) was the best treatment that gave the highest absolute growth for weight and length, eventhough for feed efficiency showed no significant difference with P4 ( 4 ton/ha). All treatments showed that the ammonia concentration increased in the final day of research (day 90th of culture) (Figure 8). 
Table 2. survival, growth and feed efficiency of catfish

\begin{tabular}{llllll}
\hline Variable & & \multicolumn{3}{c}{ Treatments } \\
& P1 & P2 & P3 & P4 & P5 \\
& $(1$ ton/ha) & $(2$ ton/ha) & $(3$ ton/ha $)$ & (4 ton/ha) & (5 ton/ha) \\
\hline Survival (\%) & $67^{\mathrm{a}}$ & $90^{\mathrm{b}}$ & $97^{\mathrm{c}}$ & $100^{\mathrm{c}}$ & $100^{\mathrm{c}}$ \\
Absolute growth of weight (g) & $9.91^{\mathrm{a}}$ & $25.21^{\mathrm{b}}$ & $30.69^{\mathrm{c}}$ & $34.98^{\mathrm{d}}$ & $40.69^{\mathrm{e}}$ \\
Absolute growth of length (cm) & $3.18^{\mathrm{a}}$ & $7.03^{\mathrm{b}}$ & $7.86^{\mathrm{c}}$ & $8.48^{\mathrm{c}}$ & $9.35^{\mathrm{d}}$ \\
Feed eficiency (\%) & $58.57^{\mathrm{a}}$ & $91.57^{\mathrm{b}}$ & $98.96^{\mathrm{c}}$ & $107.67^{\mathrm{d}}$ & $110.97^{\mathrm{d}}$ \\
\hline
\end{tabular}

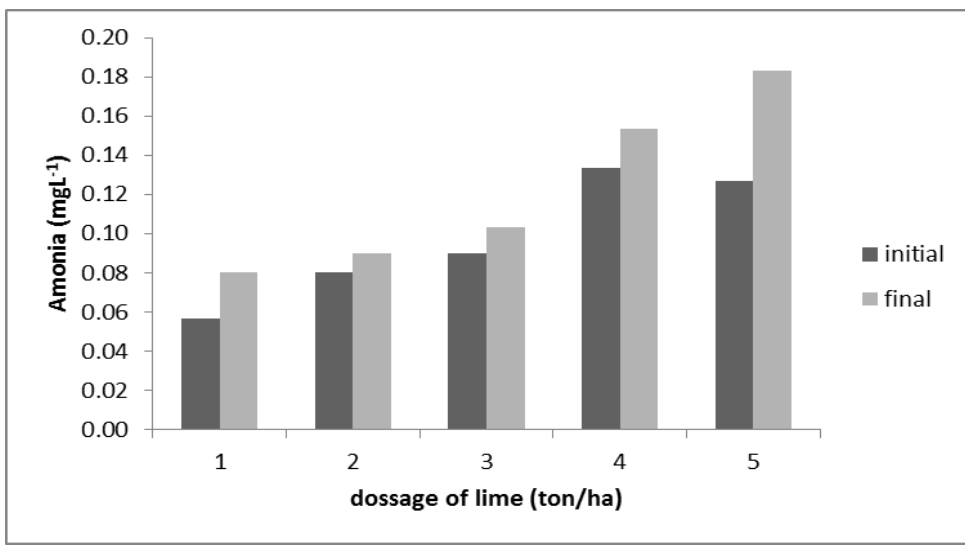

Figure 8. Ammonia konsentration in the initial (day 0 of culture) and final (day 90 of culture)

\section{Discussions}

The initial soil's $\mathrm{pH}$ before liming was 3.9, then soil $\mathrm{pH}$ increased to $5.8(\mathrm{P} 1), 6.2(\mathrm{P} 2), 6.4$ (P3), 6.7 (P4) and $7.2(\mathrm{P} 5)$, as affected by lime application during 7 days incubation time, respectively. It was showed that application of lime materials derived from $A$. granosa shell positively influenced pf of soils. The higher dosage of lime resulted the higher soil $\mathrm{pH}$, Lime derived from A. granosa shells contained 61.16 $\% \mathrm{CaO}$ and $21.65 \% \mathrm{MgO}$. Reaction between $\mathrm{CaO}$ or $\mathrm{MgO}$ and $\mathrm{H}_{2} \mathrm{O}$ produced $\mathrm{Ca}(\mathrm{OH})_{2}$ or $\mathrm{Mg}(\mathrm{OH})_{2}$ and eventually increased soil or water $\mathrm{pH}$. According to Helfrich et al. (2009), liming is the addition of limestone primarily calcium carbonate to neutralize acid water and soils, as well as buffer them from rapid fluctuations of $\mathrm{pH}$.

The increase of the ponds water's $\mathrm{pH}$ due to liming applicatios can be explained according to Boyd et al. (2002). Liming materials react with acidity sources such as $\mathrm{H}^{+}, \mathrm{Al}^{3+}$ and carbondioxide $\left(\mathrm{CO}_{2}\right)$ as illustrated below :

$$
\begin{array}{ll}
\mathrm{CaCO}_{3}+2 \mathrm{H}^{+} & \longrightarrow \mathrm{Ca}^{2+}+\mathrm{CO}_{2}+\mathrm{H}_{2} \mathrm{O} \\
\mathrm{CaCO}_{3}+\mathrm{CO}_{2}+\mathrm{H}_{2} \mathrm{O} & \longrightarrow \mathrm{Ca}^{2+}+2 \mathrm{HCO}_{3}^{-} \\
\mathrm{CaO}+2 \mathrm{H}^{+} & \longrightarrow \mathrm{Ca}^{2+}+\mathrm{H}_{2} \mathrm{O} \\
\mathrm{CaO}+2 \mathrm{CO}_{2}+\mathrm{H}_{2} \mathrm{O} & \longrightarrow \mathrm{Ca}^{2+}+2 \mathrm{HCO}_{3}^{-} \\
\mathrm{Ca}(\mathrm{OH})_{2}+2 \mathrm{H}^{+} & \longrightarrow \mathrm{Ca}^{2+}+2 \mathrm{H}_{2} \mathrm{O} \\
\mathrm{Ca}(\mathrm{OH})_{2}+2 \mathrm{CO}_{2} & \longrightarrow \mathrm{Ca}^{2+}+2 \mathrm{HCO}_{3}^{-} \\
\quad \text { Carbonate, } & \text { oxide, } \text { or hydroxide of }
\end{array}
$$
magnesium will react to neutralize acidity in the same manner as illustrated above for calcium compounds. According to Quieros et al. (2004), the application of calcium carbonate can be explained by the following reaction :

$$
\mathrm{CO}_{3}^{-2}+\mathrm{H}_{2} \mathrm{O} \leftrightarrow \mathrm{HCO}_{3}^{-}+\mathrm{OH}^{-} \text {. }
$$

Thus, when the concentration of carbonate ions increase the water, the previous chemical equilibrium (Reaction 6) moves to the right with the production of bicarbonate and hydroxyl ions. The latter ion increases the water's $\mathrm{pH}$.

The highest maximum water's $\mathrm{pH}$ among treatments was observed on P5 (5 ton/ha) with maximum $\mathrm{pH}$ value 7.9 at day 87 . Considering that water $\mathrm{pH}$ of 6.5 is the lowest for optimal growth of Pangasius sp., all lime treatments but $\mathrm{P} 1$ (1 ton/ha equivalent $\mathrm{CaO}$ ) reached the optimal $\mathrm{pH}$. The higher is the lime dosage, the higher is maximum water $\mathrm{pH}$ reached and the longer is time needed. According to equations shown in Fig 4, the maximum water $\mathrm{pH}$ days after lime application to reach maximum $\mathrm{pH}$ were 5.4 at 19 days after liming, 6.7 at 52 days after liming, 7.1 at 56 days after liming, 7.4 at 80 days after liming and 7.9 at 87 days after liming, respectively for P1, P2, P3, P4 dan P5. Furthermore, based on the equations (Fig. 4) and minimum water $\mathrm{pH}$ (6.5) for optimal growth of Pangasius sp, the next lime application should be considered after day $83^{\text {rd }}, 109^{\text {th }}, 173^{\text {rd }}$ and $205^{\text {th }}$ for P2, P3, P4 and P5, respectively.

Treatments P2, P3, P4 and P5 presented alkalinity mean values above $20 \mathrm{mg} \mathrm{L}^{-1}$, and it is within the range of ideal alkalinity values for fish rearing according to Boyd and Tucker (1998). 
The higher is the lime dosage applied to bottom soil of pond, the higher is the water alkalinity achieved as shown in Fig. 5. Liming is recommended when $\mathrm{pH}$ are below 6.5, also hardness and alkalinity are below $20 \mathrm{mg} / \mathrm{L}$ (Boyd and Tucker, 1998). Water used for Pangasius sp. rearing in this current study has $\mathrm{pH}$ of 3.9, therefore it is expected to have low alkalinity and hardness. In low water exchange units, liming can be successfully carried out to increase water $\mathrm{pH}$ and alkalinity. Besides, lime derived from $A$. granosa shell used in this research contained high $\mathrm{CaO}(61.16 \%)$ and $\mathrm{MgO}(21.65 \%)$. Therefore, it also can increase the calcium and Magnesium ion concentration of water (water hardness) (Cavalcante et al. 2009). Calsium and magnesium ions are the primary cause of hardness in natural waters (Helfrich et al. 2009). These treatments showed hard waters (hardness $>100 \mathrm{mgL}^{-1}$ ) that is usually have high calcium and/or magnesium and are less prone to acidification. According to Burtle (2015), lime should be applied to soil or water when the hardness of water is below $25 \mathrm{mgL}^{-1}$.

The water temperature and dissolved oxygen of the ponds remained within the appropriate range for normal growth of juvenile Pangasius sp (SNI 2000) ranging from $27^{\circ} \mathrm{C}$ up to $30^{\circ} \mathrm{C}$ for temperature and $>5 \mathrm{mg} \mathrm{L}^{-1}$ for Dissolved Oxygen. No significant influence of lime application on dissolved oxygen at the end of rearing period was detected. On average, the water temperature and dissolved oxygen were $28.8 \pm 2.9^{\circ} \mathrm{C}$ and $5.02 \pm 1.03 \mathrm{mg} \mathrm{L}^{-1}$, consecutively. Some data of temperatures and dissolved oxygen exceeded the optimal value but still in tolerance range for Pangasius sp. rearing.

The high survival rate on $\mathrm{P} 2, \mathrm{P} 3, \mathrm{P} 4$ and $\mathrm{P} 5$ indicates that the water $\mathrm{pH}$ is within the tolerant or optimal values of $\mathrm{pH}$ for Pangasius $s p$. growth. The highest survival, absolute growth and feed efficiency was achieved on highest dosage among all treatments (P5 : 5 ton/ha equivalent to $\mathrm{CaO}$ ). Therefore, increase dosage of lime is recomended to further studied. Queiroz et al. (2004) demonstrated that liming increases pond water alkalinity and hardness, corrects water $\mathrm{pH}$, and therefore, it is beneficial to fish yield. In acid water, lime increases the $\mathrm{pH}$ and consequently, aquatic life survival, reproduction and growth rates (Tavares et al. 2003). The beneficial of liming fish ponds i.e. (1) liming can increase concentration of calcium that is an essential element for fish growth and health, (2) liming neutralizes acidity and increases $\mathrm{pH}$, alkalinity and hardness to levels that encourage plankton as natural fish food then it became support of fish growth (3) liming not only adds calcium, but also releases absorbed elements (phosphorus and carbon) important to the growth and support of aquatic life (Cavalcante, 2009; Helfrich et al. 2009).

\section{Acknowledgement}

We would like to thank Institute for Research and Community Services, Sriwijaya University that had funded this study through Competetive Grant 2017.

\section{References}

APHA (American Public Health Association). 2012. Standard Methods for the Examination of Water and Wastewater, 22nd Edition. American Water Works, Washington D.C. 541 pp.

Boyd, C.E. and C.S. Tucker. 1998. Pond Aquaculture Water Quality Management. Kluwer Academic Publisher, London. 700 pp.

Boyd, C. E., M. Boonyaratpalin, and T. Thunjai. 2002. Properties of liming materials. Aquaculture Asia, 7 : 7-8.

Burtle G.J. 2015. Pond fertilization and liming in Georgia. UGA Extension Bulletin 867 : 1-7 pp.

Cavalcante, D. dH., A. dS. Poliato, D.C. Riberio, F.B. Magalães, and M. V. dCe Sá. 2009. Effects of $\mathrm{CaCO}_{3}$ liming on water quality and growth performance of fingerlings of Nile tilapia, Oreochromis niloticus. Acta Scientiarum, Animal Science, 31: 327-333.

Helfrich, L.A., R.J. Neves and J. Parkhurst. 2009. Liming Acidified Lakes And Ponds. Virginia Cooperative Extension publication 420-254, Virginia State University, Petersburg. pp 1-6.

Johnson, P. and P. Gerbeaux. 2004. Wetland Types in New Zealand. Wellington New Zealand: Manager, Science \& Research Unit, Science Technology and Information Services, Department of Conservation, Wellington. pp 26-37.

Jubaedah, D., M.M. Kamal, I. Muchsin, and S. Hariyadi. 2015. Karakteristik kualitas air dan estimasi resiko ekobiologi (Water Quality Characteristics and Estimation of Ecobiological Risk of Herbicide in Lubuk Lampam Floodplain, South Sumatera ). $J$. Manusia dan Lingkungan, 22(1) : 12-21.

Nobre, M. K. B., F. R. D. S. Lima, F. B. Magalhães, and M. V. D. C. E Sá. 2014. Alternative liming blends for fish culture. Acta Scientiarum. Animal Sciences, 36(1): 1-11.

Queiroz, J.F., G. Nicolella, C.W. Wood, and C.E. Boyd. 2004. Lime application methods, water and bottom soil acidity in fresh water fish ponds. Scienta Agricola, 61 : 469-475. 
SNI (Standar Nasional Indonesia). 2000. Produksi benih ikan patin siam (Pangasius hypopthalmus) kelas benih sebar. Jakarta, 13 pp.

Tavares, S., L.H. Gomes, J.P.G. dOS S and F.M. dES Braga. 2003. Effect of liming management on the water quality in Colossoma macropomum (Tambaqui), ponds. Acta Limnol. Bras., 15 :95-103.

Vijayakumar, P. and R. Vasudeva. 2011. Characterization of soil properties from fresh water swamps and adjoining evergreen forest area. Karnataka J. Agric. Sci., 24(4) : 601602.

Wilkinson, S. 2002. The use of lime, gypsum, alum and potassium permanganate in water quality management. Aquaculture Asia : 12-14.

Wynne, F. 1996. The use of Agricultural Limestone and Gypsum in Ponds. 8th Triennial National Wildlifw \& Fisheries Extension Specialis Conference. University of Nebraska-Lincoln. 